\title{
LAS CLAVES DE TEDESCHINI. LA POLÍTICA VATICANA EN ESPAÑA (1921-1936)
}

\author{
The keys of Tedeschini. The Vatican in Spain during \\ the interwar period (1921-1936)
}

\author{
JOSÉ RAMÓN RODRÍGUEZ LAGO \\ Universidad de Vigo \\ jrlago@uvigo.es
}

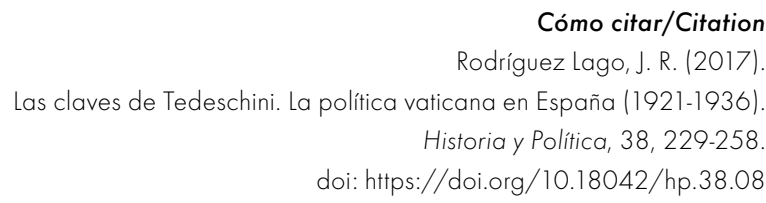

(Recepción: 26/04/2016. Evaluación: 27/06/2016. Aceptación: 05/09/2016. Publicación: 10/11/2017)

\section{Resumen}

El análisis de la documentación generada por la Nunciatura de Madrid y la Secretaría de Estado del Vaticano durante los quince años de gestión del nuncio Federico Tedeschini permite adentrarse en la visión que la curia pontificia tuvo del desarrollo de los acontecimientos en la Espańa de entreguerras y en la aplicación de las diversas estrategias eclesiásticas adoptadas en defensa de sus intereses. Un estudio que evidencia cómo las dinámicas internas de la Iglesia en España se vieron condicionadas por el complejo juego dialéctico atravesado en aquellos ańos por una corporación cada vez más centralizada y global.

\section{Palabras clave}

Iglesia; España; Vaticano; Primo de Rivera; Segunda República. 


\begin{abstract}
The management of Federico Tedeschini as Nuncio in Madrid for fifteen years enables us to enter in the vision of the Papal curia about the development of events in Spain during the interwar period and the implementation of various ecclesiastical strategies adopted in pursuit of their interests. The analysis of the documentation generated by the Nunciature and by the Vatican Secretary of State brings to light how the internal dynamics of the Church in Spain were conditioned by a complex and dialectical interplay that it was experienced at that time for a corporation increasingly global and centralized.
\end{abstract}

\title{
Keywords
}

Church; Spain; Vatican; Primo de Rivera; Second Spanish Republic. 


\section{SUMARIO}

I. INTRODUCCIÓN. II. LA CLAVE GLOBAL. EL VATICANO Y ESPAÑA EN LA EUROPA DE ENTREGUERRAS. III. LA CLAVE PERSONAL. EL EXILIO DEL FAVORITO Y LA HOGUERA DE LAS VANIDADES. IV. LA CLAVE TERRITORIAL. COMPRENDER ESPAÑA DESDE LA VILLA Y CORTE. V. LA CLAVE CLERICAL. EL PODER DE UNA BIRRETA. VI. LA CLAVE SOCIAL. POCOS Y MAL AVENIDOS. VII. LA CLAVE POLÍTICA. EXTRAÑOS ALIADOS Y ENEMIGOS ÍNTIMOS. VIII. CONCLUSIÓN. BibLIOGRAFÍA.

\section{INTRODUCCIÓN}

Pocas personalidades relevantes en la España del siglo xx han resultado tan aludidas en comparación con su exiguo análisis historiográfico como Federico Tedeschini, quien durante quince años ejerció como nuncio apostólico en Madrid. La apertura a los investigadores de los fondos del Archivo Secreto Vaticano producidos por la nunciatura y la sección de Asuntos Eclesiásticos Extraordinarios de la Secretaría de Estado permite ofrecer una interpretación que, más allá de la relación descriptiva del amplio volumen de documentación generada durante su gestión, nos adentre en las claves por las que esta se vio condicionada ${ }^{1}$. Los informes elaborados por el nuncio para las altas instancias vaticanas, las respuestas o los significativos silencios de estas, o el reflejo en la prensa de las polémicas relacionadas con el negocio de los asuntos católicos en aquellos años, muestran pistas significativas para una mejor comprensión, no solo del papel jugado por las instituciones eclesiásticas, sino del desarrollado por otros organismos como la dinastía borbónica, los diversos gobernantes, los dirigentes de las organizaciones políticas y los intelectuales más prominentes, juzgados a la luz de los ojos del nuncio y de la Secretaría de Estado.

Fueron muchos los que afirmaron entonces que Tedeschini era uno de los mejores conocedores de la realidad espańola. Sin presuponer de antemano que esto pudiese ser cierto, conviene sacar partido de todo ese caudal de conocimiento para establecer un diálogo entre las valiosas fuentes por él generadas

\footnotetext{
Una panorámica de esta documentación puede apreciarse en los trabajos de Cárcel (2008; 2007a; 2007b; 2005; 1999); Martínez Álvarez (2015) para el período de la dictadura de Primo de Rivera, o Trullén (2012) y Robles (2013; 2015) para la etapa de la II República.
} 
y la menguada producción historiográfica existente hasta la fecha. Frente al estudio pormenorizado de su gestión en cuestiones particulares, un análisis conjunto de la odisea española de Tedeschini nos adentra en claves que sugieren nuevas vías de investigación.

\section{LA CLAVE GLOBAL. EL VATICANO Y ESPAÑA EN LA EUROPA DE ENTREGUERRAS}

Federico Tedeschini llega, actúa y se marcha de España como emisario diplomático del Vaticano. La constatación de tal obviedad exige que la interpretación de sus acciones se vea sujeta a un conocimiento exhaustivo de la evolución del complejo entramado de la curia vaticana durante esos quince procelosos años. Como es natural, el nuncio en Madrid responde tanto o más a las demandas, ofertas y los giros estratégicos producidos en la sede pontificia, que a la evolución de los acontecimientos en España. Y siendo esto así para todos y cada uno de los agentes papales que transitaron por la villa y corte en los años precedentes, lo fue todavía más en el caso de Tedeschini por múltiples razones. Su etapa de gobierno coincidió con un marcado proceso de centralización de las instancias vaticanas por el que los pontífices incrementaron sus competencias, no solo limitando las tradicionales prerrogativas de los diversos patronos en materia eclesiástica, sino también las de los nuevos delegados apostólicos, sometidos ahora a un seguimiento más estricto. La drástica transformación de la curia ejecutada durante el pontificado de Pío X en junio de 1908 y continuada por Benedicto XV; la entrada en vigor en mayo de 1918 de un código de derecho canónico que afectó por primera vez en la historia a todas las diócesis del orbe, y la ampliación de la dimensión carismática del papado, supusieron nuevos pasos en ese determinante proceso de centralización ${ }^{2}$.

Cuando Tedeschini fue nombrado nuncio en Madrid, el Vaticano ostentaba ya representación diplomática oficial en veintisiete Estados. Si hasta septiembre de 1914, a las monarquías de España, Bélgica, Serbia y Baviera y los imperios austrohúngaro, prusiano y ruso se sumaban únicamente algunas de las repúblicas americanas, tras la revolución soviética y la derrota de los imperios centrales, Benedicto XV se inclinó por establecer relaciones diplomáticas con las repúblicas de Francia o Portugal — con un largo historial de conflictos con el Papado-, con Estados de arraigada tradición protestante como Gran Bretaña, Suiza o los Países Bajos, y con las naciones emergentes en la Europa posbélica. El proceso de radicales transformaciones que se observó en el mapa

2 Pollard (2014; 2005; 1999). 
del viejo continente generó nuevas oportunidades para los Estados y para las corporaciones transnacionales que, como el Vaticano, habían sobrevivido a la catástrofe bélica; especialmente para las potencias vencedoras, que aprovecharon los tratados de paz para obtener contrapartidas muy favorables a sus intereses, pero también, aunque en menor medida, para los que habían apostado por la neutralidad y pretendían jugar sus bazas como mediadores. El cuerpo diplomático del Vaticano contaba con la selecta formación recibida en las instituciones creadas durante el pontificado de León XIII y su aliado en la Secretaría de Estado, el cardenal Mariano Rampolla, convertidas en auténtico think tank del catolicismo; una refinada elite burocrática sujeta a mayores controles por una curia que ansiaba garantizar una gestión más fiel a Roma y más independiente respecto a los poderes locales. Federico Tedeschini, conviene tenerlo en cuenta, dispuso así de un poder más limitado que el otorgado a los anteriores delegados pontificios. En múltiples ocasiones, el monarca y las oligarquías acostumbradas a valerse de los favores del nuncio para conseguir sus deseos ante Roma, achacaron al nuevo emisario su debilidad y se sintieron decepcionados por la creciente dependencia de los designios romanos ${ }^{3}$.

La acción diplomática de Tedeschini vino marcada también por circunstancias más coyunturales, en base a los giros no solo estratégicos, sino también doctrinales de la política pontificia. Una política atenta a la coyuntura internacional de cada momento, pero muy influenciada al mismo tiempo por la orientación ideológica y el carácter personal de cada uno de los pontífices y de sus alter ego en la Secretaría de Estado. El gobierno eclesial de Benedicto $\mathrm{XV}$ potenció los cauces diplomáticos para desempeñar un papel crucial en una Europa cristiana que todavía lamía sus heridas de guerra. La expansión inicial en la Europa reconstruida de las tesis democráticas amparadas por el Plan Wilson se correspondió con una mayor atención al emergente catolicismo norteamericano ${ }^{4}$, pero también con el acercamiento a la República

3 Informe enviado al papa Pío XI por el sacerdote José Solé y Mercadé, auditor-asesor de la Nunciatura Apostólica de Madrid (agosto de 1922). Archivio Nunziatura Madrid. Arquivio Segreto Vaticano (en adelante ASV, ANM), Caja 778: 246-253.

4 A la creación de la National Catholic War Council en 1917 le siguió la National Catholic Welfare Council en 1919, que desde 1922, tras arduas negociaciones entre la curia vaticana y el episcopado norteamericano, pasó a denominarse National Catholic Welfare Conference. Siempre bajo las siglas de la NCWC, la organización desarrolló toda una serie de exitosas campañas que acabarían influyendo notablemente en las políticas vaticanas. El Congreso Eucarístico Internacional celebrado en Chicago en junio de 1926 confirmaría rotundamente el éxito de esta propuesta. Dolan (2002). 
Francesa y a la monarquía británica, la atenta negociación con los diversos Estados surgidos tras la desintegración de los imperios centrales y la tentativa por incrementar la influencia en la Rusia poszarista ${ }^{5}$. La experiencia atesorada por Rampolla y sus partidarios en la política de ralliement con Francia, y la influencia de los católicos de los Estados Unidos en el ámbito financiero y la praxis organizativa, sin excluir componentes doctrinales, resultaron decisivas en esta estrategia: una mayor participación en la esfera de las misiones, la promoción de grandes campañas de acción social y cierta predisposición a permitir la participación de los católicos y sus partidos en la competencia electoral y el juego parlamentario de las democracias representativas. En 1919, Benedicto XV, asesorado por su nuncio en Múnich, Eugenio Pacelli, alentaría en Baviera la formación del Partido Social Católico; unas semanas más tarde, el mismo pontífice anulaba el non expedit decretado por Pío IX y arropaba la fundación del Partito Popolare Italiano liderado por el sacerdote Luigi Sturzo.

El posterior pontificado de Pío XI, marcado desde sus inicios por la implantación del fascismo en Italia y el progresivo proceso de degradación de los regímenes democráticos, se caracterizó sin embargo por la restauración de un modelo eclesial en el que concepto de hierocracia y los parámetros estrictamente confesionales marcaron distancias frente al liberalismo y las religiones políticas emergentes ${ }^{6}$. Una diplomacia dispuesta a proseguir en la senda de la negociación con los Gobiernos, pero muy reacia a participar en la arena del enfrentamiento partidista, siempre tildado de peligroso; una estrategia que, en función de la ansiada virtud de la estabilidad, fue proclive a alcanzar acuerdos con los nuevos Estados autoritarios; especialmente cuando algunos de ellos, al uno y al otro lado del Atlántico, esgrimieron un emergente discurso nacionalcatólico que conjugaba las virtudes eclesiásticas y las castrenses?.

Los cambios en la curia y en las directrices de la política vaticana se reflejaron así en la acción del nuncio, como no podía ser de otra manera, pero como pocas veces se ha constatado. El diálogo abierto con el grupo de la Democracia Cristiana liderado por Severino Aznar, y su apoyo al proyecto de la Gran Campaña Social que, siguiendo el modelo desarrollado en los Estados Unidos y en Argentina, pretendía impulsar Ángel Herrera, se vio inmediatamente sustituido por un claro distanciamiento de estas orientaciones tras el repentino fallecimiento de Benedicto XV y la elección en el conclave subsiguiente de Pío

Rodríguez (2012a).

6 Menozzi y Moro (2004); Fattorini (2013; 2007); Leonardis (2014), y Kertzer (2014).

7 En Latinoamérica resulta muy apreciable en los Gobiernos de Gómez Chacón en Venezuela, Terra en Uruguay o Uriburu y Justo en Argentina. Para el contexto europeo, véase Botti, Montero y Quiroga (2013). 
XI. En esas mismas fechas, resultó todavía más relevante la eliminación de la carrera por la primacía de Toledo del cardenal Juan Bautista Benlloch, favorito del papa Della Chiesa, rápidamente apartado de la carrera sucesoria tras la coronación pontificia de Aquille Ratti ${ }^{8}$.

Años más tarde, la incertidumbre generada por la dimisión del general Primo de Rivera coincidiría a su vez con el viraje diplomático introducido por Eugenio Pacelli al hacerse con el control de la Secretaría de Estado. Un Pacelli que, tras su acrisolada experiencia diplomática en Alemania', se mostraría firme partidario de establecer, no solo negociaciones concordatarias que garantizasen las posiciones eclesiales con los regímenes políticos que - al margen de su modelo de Estado- garantizasen cierta estabilidad, sino de adentrarse en el juego parlamentario y las dinámicas electorales, que Pío XI seguiría juzgando con desconfianza ${ }^{10}$. El giro estratégico cursado entonces por su antiguo compañero y amigo sorprendió notablemente a Tedeschini, que reflejó muy pronto sus escasas convicciones en aquella aventura, exponiendo en privado las dificultades que podrían encontrarse en España para abandonar la tesis férreamente anclada en los años previos ${ }^{11}$.

Tedeschini debió asumir entonces un proyecto de conciliación con la aventura republicana marcado en todo momento por expresa instancia de la Secretaría de Estado. Un proyecto posibilista por el que el nuncio en Madrid solo comenzó a mostrar cierta confianza en octubre de 1932, tras convencer a Ángel Herrera, el único católico español que mereció siempre sus elogios, para asumir la dirección de Acción Católica ${ }^{12}$. En la primavera de 1933 la nueva organización parecía ir tomando forma, pero los resultados obtenidos por la Acción Popular de Gil Robles fueron los que supusieron para Tedeschini «el primer rayo de sol» tras dos años de lúgubres penumbras ${ }^{13}$. Desde ese

8 Informe del nuncio a Secretaría de Estado (31 de marzo de 1922). Affari Ecclesiastici Straordinarii. Archivio Segreteria di Stato (en adelante, AAEESS), Spagna IV, Fascículo 32: 2-7.

9 Fattorini (1992).

10 Informe del Secretario de Estado del Vaticano, Eugenio Pacelli, al nuncio (26 de abril de 1931). AAEESS, Spagna IV, Fascículo 117: 90.

11 Informe del Nuncio a Eugenio Pacelli (2 de septiembre de 1931). AAEESS, Spagna IV, Fascículo 118: 21.

12 Del nuncio a Pacelli sobre el candidato Ángel Herrera (1 de octubre de 1932). ASV, ANM, Caja 956: 348-353. Sobre el desarrollo de la Acción Católica dirigida por Ángel Herrera, véase Montero (2008).

13 Informe del nuncio a la Secretaría de Estado sobre las elecciones municipales parciales (26 de abril de 1933). AAEESS, Spagna IV, Fascículo 178: 58-60. 
momento, el proyecto social y político diseñado por Herrera contaría con su confianza plena, incluso hasta el mismo día de su regreso a Roma, en una situación mucho más dramática de la que él nunca hubiese sospechado.

En aquellos intensos años del periplo republicano, Tedeschini se sintió abandonado por las altas instancias vaticanas que le exigían cumplir con los designios de la Secretaría de Estado mientras se resistían a manifestar públicamente su apoyo expreso a su más cualificado representante en España. En febrero de 1932 confesó amargamente ante Pacelli su malestar con la actitud adoptada por Giuseppe Pizzardo. Su sucesor como sustituto en la Secretaría de Estado ejercía ahora como secretario de la Sagrada Congregación de Asuntos Eclesiásticos Extraordinarios, encargado al tiempo de extender el modelo romano de Acción Católica al resto del orbe, y contaba con el poder y la confianza que Tedeschini había perdido. Pizzardo se presentaría en España para dar carta de naturaleza oficial a Acción Católica, y desde enero de 1933 tutorizaría la aventura política de Gil Robles en la conformación de la CEDA ${ }^{14}$. Finalmente, en abril de 1936, sería el encargado de trasmitir a Tedeschini que su aventura española debería dar paso a un nuevo emisario para un nuevo tiempo ${ }^{15}$.

\section{LA CLAVE PERSONAL. EL EXILIO DEL FAVORITO Y LA HOGUERA DE LAS VANIDADES}

Tedeschini había llegado a Madrid quince años antes, precedido de la insistente rumorología extendida entre la curia sobre su condición de favorito de Benedicto XV. Tras la coronación de Della Chiesa, dos jóvenes eclesiásticos habían sobresalido como figuras rutilantes en la Secretaría de Estado. Ambos se habían formado en el regazo del cardenal Mariano Rampolla y ambos adquirieron pronto influencia y prestigio. El 4 de septiembre de 1914, la misma tarde de su proclamación como nuevo pontífice, Benedicto XV decidió mantener en su cargo a Eugenio Pacelli, ocupado desde hacía solo unos meses de la Sección de Asuntos Eclesiásticos Extraordinarios. Federico Tedeschini fue designado sustituto de la Secretaría de Estado y el cardenal Domenico Ferrata, que contaba 67 años, se hizo cargo del organismo más poderoso de la curia romana. Los nombramientos suponían

14 Informe del nuncio a Pacelli (25 de marzo de 1932). ASV, ANM, Caja 892: 200-223.

15 Carta de Giuseppe Pizzardo al nuncio (29 de abril de 1936). ASV, ANM, Caja 956: 325 . 
toda una declaración de intenciones. No solo alejaban de los resortes diplomáticos a los aliados de Merry del Val, que los habían dominado a su antojo durante más de una década; también catapultaba a la cúspide de la curia al eclesiástico que se había ganado la admiración o la animadversión de muchos por su mediación como nuncio ante el Reino de Bélgica y la República Francesa.

Solo un mes más tarde, el inesperado fallecimiento de Ferrata interrumpió los planes iniciales del pontificado y forzó a Benedicto XV a nombrar un nuevo secretario de Estado. Desde el 13 de octubre de 1914, Pacelli y Tedeschini, de 38 y 41 años respectivamente, se vieron sometidos a las órdenes del cardenal Pietro Gasparri, que a sus 62 años, y tras haberse ocupado en los años previos de la redacción del Código de Derecho Canónico, había ejercido como influyente camarlengo en el cónclave anterior. Muy pronto el protagonismo de Tedeschini y su relación de confianza con el papa, llegó a poner en cuestión la dirección de la Secretaría de Estado. Si Pío $\mathrm{X}$ se había sentido subyugado por la influencia del joven Merry del Val, que con solo 38 años y sin ostentar cargo de cardenal había sido elegido secretario de Estado, los mentideros de Roma presumían que el nuevo pontífice se sentía ahora tentado a otorgar a Tedeschini el mismo cargo. En mayo de 1917 Pacelli fue destinado nuevo nuncio en Munich y Tedeschini permaneció en Roma para asumir en primera persona la defensa del papa ante el tribunal militar formado para dictar sentencia sobre el espinoso affair Gerlach ${ }^{16}$. $\mathrm{Su}$ estrella pareció ascender de tal modo que el mismo Gasparri se sintió amenazado, inaugurando una etapa de desencuentros ${ }^{17}$. Las noticias sobre la proclamación inminente de Tedeschini como cardenal fueron constantes,

16 Monseñor Rudolph Gerlach era un joven eclesiástico de origen bávaro formado en la Academia de Nobles Eclesiásticos. Mientras servía como camarero secreto de Benedicto XV, fue acusado por los servicios de contraespionaje italianos de trabajar como espía en favor de los imperios centrales. Condenado a cadena perpetua por un tribunal militar, logró huir a Suiza, generando gran tensión en el seno de la curia y entre la opinión pública italiana. Véase Pollard (2014): 51-54.

17 Entre las numerosas noticias aparecidas en la prensa española sobre la especial sintonía entre Benedicto XV y Tedeschini, sobresale el desmentido del $A B C$ sobre las noticias publicadas por la Agencia Radio y El Corriere de La Sera respecto al próximo nombramiento de Tedeschini como cardenal y secretario de Estado (13 de septiembre de 1916); o la entrevista efectuada a Tedeschini por Franco Franchi, corresponsal de este mismo diario en Roma (9 de agosto de 1917), posteriormente desmentida por el Osservatore Romano (18 de agosto de 1917). Zúniga (1929), mientras se orquestaba la campaña de homenaje al nuncio, relata múltiples detalles de la muy estrecha relación entre Tedeschini y el papa Della Chiesa. 
pero la resistencia de una parte de la curia y el no haber gestionado previamente cargo de gobierno alguno, parecían impedirlo. Finalmente, en marzo de 1921 Benedicto XV designó a Tedeschini nuevo nuncio en Madrid. Su destino en Espańa podría servir de excelente aval curricular para su próximo nombramiento como cardenal y su hipotético ascenso a la más alta dirección de la política vaticana.

Tedeschini llegaba pues a Madrid, entre otros motivos, para garantizar su próxima birreta cardenalicia; pero su misión tenía además otro significado relevante. Benedicto XV era un buen conocedor de la Iglesia española. En su juventud había ejercido como secretario de la nunciatura del cardenal Rampolla sufriendo en primera persona las luchas intestinas suscitadas por las diversas corrientes enfrentadas en el seno de la Iglesia española. Durante el pontificado de Pío X, los seguidores de Merry del Va ${ }^{18}$ habían reforzado sus posiciones. Ahora, el antiguo secretario de Estado había sido desplazado a la Sagrada Congregación del Santo Oficio, pero su grado de influencia seguía manifestándose con especial vehemencia en la corte borbónica y entre la aristocracia española. Si en junio de 1914 la Comunión Integrista recibió el apoyo de numerosos obispos en su acto de consagración del Sagrado Corazón de Jesús en Madrid, en mayo de 1915, en el delicado contexto de la entrada de Italia en la guerra, Alfonso XIII se apresuró a ofrecer el monasterio de El Escorial como glorioso asilo del pontífice; y en mayo de 1919 el acto de consagración nacional de España ante el monumento al Sagrado Corazón, bendecido con la presencia del monarca y los representantes del Gobierno, proclamó la hegemonía del discurso integrista, que no parecía admitir resquicio alguno para un catolicismo conciliador con los nuevos tiempos ${ }^{19}$. Como prueba definitiva de esta deriva, la condena emitida en marzo de 1921 por el episcopado sobre el grupo de la Democracia Cristiana, supondría el canto del cisne del nuncio Francesco Ragonesi, a quien Merry del Val había designado legado $a$ latere de Pío X en 1913.

La llegada de Tedeschini a la capital del reino auguraba, pues, un nuevo tiempo. Benedicto XV, que había esquivado como arzobispo de Bolonia el ímpetu de la caza de brujas desatada por la condena de las corrientes

18 Rafael Merry del Val y Zulueta presidió la Academia Pontificia de Nobles Eclesiásticos entre 1900 y 1903. Secretario del cónclave que coronaría a Pío X como papa, fue nombrado prosecretario de Estado esta misma tarde, y convertido en brazo derecho del pontífice desató una batalla contra el modernismo teológico. En agosto de 1925 su hermano Alfonso, embajador del Reino de España en Londres, recibió de Alfonso XIII el título de marqués de Merry del Val.

19 Montero (2014). 
modernistas, intentaría extender en España sus tesis conciliadoras, pero su estrategia se vería muy pronto dinamitada por los designios de la naturaleza. En enero de 1922, el fallecimiento simultáneo y en ambos casos inesperado del pontífice y del cardenal Enrique Almaraz Santos, recientemente nombrado primado de España, echó por tierra los planes diseńados junto al nuncio. La coronación papal de Aquille Ratti, con quien Tedeschini había tenido algunas disputas durante su actuación como delegado apostólico en Polonia, frustraba su designación como cardenal y ponía trabas para un regreso laureado a la curia vaticana ${ }^{20}$. Pío XI y Pietro Gasparri forjarían ahora una alianza anclada en parámetros más conservadores que los de su predecesor. También mantendrían a Tedeschini alejado de la curia, mientras su luz se apagaba en el dorado exilio español.

Las polémicas públicas y los rumores extendidos sobre algunos sucesos que afectaban directamente a la vida privada del nuncio, como el suicidio del influyente confesor de la reina en marzo de 1923, el presumible conato de atentado en la Casa de Campo en enero de 1929, o el accidente automovilístico en el que se vio involucrado en agosto de 1933, siempre bajo el velo de la sospecha de sus compañías femeninas ${ }^{21}$, no solo preocuparían a Tedeschini por la influencia que pudiesen tener en su acción diplomática, sino por su incidencia en el cursus honorum de su ansiada promoción eclesiástica. Solo teniendo en cuenta estas circunstancias, marcadas no únicamente por las directrices llegadas desde Roma, sino también por las propias aspiraciones del delegado pontificio para agradar a una curia a la que deseaba regresar con honores, pueden explicarse una buena parte de sus actuaciones.

También los diversos homenajes al nuncio deben ser interpretados en esta clave de juego de tronos entre la jerarquía episcopal y la curia romana. Si

20 Pagano y Venditti (2013).

21 Sobre las polémicas suscitadas en torno al suicidio de Javier Vales Faílde, párroco titular de la capilla de palacio y auditor del Tribunal de La Rota espańola, véase Rodríguez (2012b). Sobre el supuesto atentado en la Casa de Campo existe prolija documentación en los informes del nuncio al comendador Pío Perrone $(5$ de febrero de 1929), al Secretario de Estado Pietro Gasparri (6 de febrero de 1929) y a Giuseppe Pizzardo (7 de febrero de 1929). ASV, ANM, Caja 789. En agosto de 1933, el automóvil en el que viajaba el nuncio se estrelló contra un árbol a la altura de Miranda del Ebro. Acompañaban a Tedeschini, su chófer, su ayudante de cámara y tres mujeres: la exmarquesa de Almoguer, Carmen Masana; la señorita Magdalena Ubagón, y una joven que - según se afirma- es sobrina del nuncio. Hospitalizado en San Sebastián y atendido por el médico Oreja Elósegui, Tedeschini se alojó en casa del párroco Julio Moya (noticias en prensa desde el 23 de agosto). Sobre uno de los libelos publicados contra el nuncio, véase Nogueira (1934). 
el celebrado en mayo de 1930 resultó en buena medida un cínico homenaje orquestado por sus máximos enemigos para proyectar la despedida de un nuncio que resultaba molesto para las tesis integristas ${ }^{22}$, el de febrero de 1936, tras recibir su birreta cardenalicia durante tanto tiempo negada o silenciada, y a escasos días de la convocatoria electoral, se produjo en un contexto de incertidumbre en el que todos, y muy especialmente el Gobierno de Portela Valladares, deseaban trasmitir una imagen de moderación ${ }^{23}$. Por último, el realizado en junio de ese mismo año, previo a su regreso a Roma, se convirtió en un epitafio cargado de oropeles para un proyecto eclesial fracasado y para un nuncio desolado por su derrota y por la trágica noticia del suicidio del que había sido su más cercano colaborador ${ }^{24}$. Es conveniente tener muy en cuenta este marco escénico en la travesía del nuncio en Madrid durante esos intensos quince años.

22 La iniciativa del homenaje fue lanzada en abril de 1929 por el sacerdote Federico Santamaría Peńa, presidente de la Liga Nacional en Defensa del Clero desde su órgano de prensa Unión y caridad. La resistencia inicial de Segura se tornó posteriormente en su apropiación del homenaje para propiciar el posible retorno del nuncio a Roma. Las ceremonias se habían proyectado en Toledo, pero tendrían lugar un año más tarde en Madrid A los elogios pronunciados por Segura, por entonces ya abiertamente enfrentado con Tedeschini, siguieron los banquetes ofrecidos por cardenal y monarca, aderezados con discursos de los partidarios del integrismo y correspondidos con lacónicas respuestas del homenajeado. Informe del acto de homenaje al nuncio (5 de mayo de 1930). ASV, ANM, Caja 789: 324-325.

23 La cadena de elogios se inicia con la celebración del Día del Papa (circular del obispo de Madrid Eijo Garay sobre el Día del Papa, 1 de febrero) y prosigue con la recepción por el ministro de Estado Joaquín de Urzaiz y Cadaval (4 de febrero) y el consiguiente banquete ofrecido por el presidente Alcalá Zamora (noticias recogidas en $E l$ Soly La Hormiga de Oro, 5 de febrero). Los halagos se extienden en revistas anteriormente críticas con el nuncio como El Sol, La Libertad o incluso El Siglo Futuro. Al banquete en palacio asisten el cardenal Gomá, el secretario de la Nunciatura Tito Crespi, el embajador ante el Vaticano Leandro Pita Romero, el presidente de la República Niceto Alcalá Zamora, el presidente de las Cortes Santiago Alba, el presidente del Gobierno Manuel Portela Valladares, el secretario de la Presidencia Rafael Sánchez Guerra y el obispo de Madrid, Leopoldo Eijo Garay.

24 El 18 de abril de 1936, el jesuita Tito Crespi, secretario de la Nunciatura durante los años previos, fallece tras arrojarse al mar mientras realizaba la travesía de regreso a Roma en el buque italiano Merano. Encomiásticos elogios al nuncio en su salida de Espańa se reflejan en el diario El Sol. ("Agradecimiento de la República», 2 de junio; «La colonia italiana de Madrid rinde un homenaje de despedida al cardenal Tedeschini», 7 de junio). 


\section{LA CLAVE TERRITORIAL. COMPRENDER ESPAÑA DESDE LA VILLA Y CORTE}

Tradicionalmente, el nuncio en Madrid había venido representando al pontífice ante la monarquía española. La dinastía borbónica seguía atesorando toda una serie de privilegios que le otorgaban un amplio control sobre las instituciones eclesiásticas. Fomentar unas relaciones de cohabitación entre el monarca y la curia vaticana se convertía así en objetivo primordial de toda nunciatura, pero esta tarea resultó una difícil encomienda durante el gobierno de Tedeschini. El proceso de centralización de la Iglesia como una corporación trasnacional dañaba los intereses de las tradicionales oligarquías que, amparadas en el privilegio del patronato, venían rigiendo los destinos de cada una de las iglesias locales; pero también chocaba con el anhelo imperialista de un monarca que exhibió una obsesiva pretensión de ejercer como privilegiado patrón del catolicismo, incluso más allá de las fronteras patrias. Alfonso XIII el Africano no solo se presentaba así mismo como el principal garante de esta confesión en el protectorado marroquí del norte de África, sino en toda Latinoamérica, o en la mismísima Palestina, donde la Tierra Santa se veía gestionada por la congregación franciscana que tenía su principal colegio de misiones en Santiago de Compostela. Si los conflictos surgidos entre el monarca y la curia romana respecto a la atención católica en Marruecos y en Tierra Santa eran ya el principal foco de preocupación previo a la llegada del nuncio ${ }^{25}$, la exaltación del discurso de la hispanidad que se apreció durante los años de la dictadura de Primo de Rivera, y que el nuncio siempre despreció, originó nuevos conflictos con el monarca.

La dependencia de las relaciones con la corte provocaba además que la imagen que Tedeschini tuviese de Espańa se viese muy condicionada por los sucesos de la capital y los ecos que a esta llegaban o se generaban sobre los más recónditos lugares de Espańa. Una visión de los acontecimientos marcadamente centralista que denotaba cierta incomprensión hacia los procesos de transformación apreciables en ciudades y territorios, donde las demandas de élites locales, cada vez más poderosas y organizadas, condicionaban la toma de decisiones, no solo en el ámbito económico y político, sino también en el eclesiástico. Si las dinámicas surgidas en Barcelona y su área metropolitana, por entonces la mayor del reino, se convirtieron en fuente de preocupación desde los primeros momentos ${ }^{26}$, fue durante la dictadura de Primo de Rivera

25 Informe de la Sagrada Congregación de Propaganda de la Fe (20 de mayo de 1921). ASV, ANM, Caja 778: 211-212.

26 Informe del nuncio a Secretaría de Estado (12 de noviembre de 1922). ASV, ANM, Caja 831: 125-127. 
cuando la obsesión anticatalanista exhibida desde los primeros días por el dictador acabó contagiando las percepciones del nuncio ${ }^{27}$. La condena a Cataluña alcanzó muy pronto al principal responsable eclesiástico de la deriva catalanista, que a los ojos de Tedeschini no era otro que el cardenal Vidal ${ }^{28}$. Solo la tenaz resistencia de la curia vaticana por mantener a Vidal en Tarragona frente a las insistentes demandas del monarca, de Primo de Rivera, del propio nuncio y de una buena parte del episcopado, evitaron su exilio en aquellos días. En febrero de 1924 el Gobierno planteó su traslado a la archidiócesis de Zaragoza; en mayo de 1926 se intentó promover su traslado a Burgos o a Valencia; y desde agosto de ese mismo año se hizo todo lo posible para encontrarle un nuevo destino en Roma ${ }^{29}$. Paradójicamente, Tedeschini se vio obligado a olvidar todas esas consideraciones previas, cuando, proclamada la República, Pacelli mostró confianza plena en la gestión de Vidal y le ordenó convertirlo en cualificado portavoz de la Iglesia española; una colaboración forzosa que alió a los antiguos enemigos en una cruda batalla bifronte contra el integrismo y el anticlericalismo.

Si Tedeschini había calificado previamente el catalanismo como uno de los peores problemas de la Iglesia española, el emerger de corrientes nacionalistas en otros territorios de España durante la II República pareció al nuncio «la peor de las plagas $»^{30}$. Un proceso que, en su opinión, no solo ponía en cuestión la estabilidad institucional del Estado, sino que dificultaba el proyecto de unidad entre los católicos cuando resultaba más urgente y necesario. Una vez más, la ventana de Madrid a Espańa parecía limitada para entender los complejos procesos desatados en la periferia. Las intrigas propias de la Corte y del séquito de Alfonso XIII, de su madre María Cristina con su propia corte de verano en San Sebastián, y de su esposa consorte, Victoria Eugenia de Battenberg, resultaron decisivas en muchas de las decisiones que afectaban a las instituciones eclesiásticas. Más determinante, si cabe, resultó el protagonismo del jesuita Alfonso Torres Fernández, que ejerció no solo como confesor y director espiritual del monarca, sino como principal autor intelectual de muchas de sus encendidas proclamas, durante su reinado y durante su exilio ${ }^{31}$.

\footnotetext{
Raguer (2011).

28 Informe final del nuncio sobre la cuestión catalanista a la Sagrada Congregación de Seminarios y Universidades (1 de octubre de 1928). ASV, ANM, Caja 386: 50-52.

29 Denuncias contra el cardenal Vidal e informes del nuncio a la Secretaría de Estado (febrero de 1924 a octubre de 1928), ANM, Caja 836: 335-586.

30 Rodríguez (2010) y Louzao (2013).

31 Alfonso Torres Fernández (1897, Zurgena, Almería-1946, Granada) ingresó en la congregación de los jesuitas de Granada en 1908, tras haber realizado carrera eclesiástica
} 
Las tensiones entre el nuncio y el monarca, y entre este último y la curia vaticana fueron permanentes, sin excluir la audiencia mantenida el 19 de noviembre de 1923 con Pío XI, cuando el monarca español insistió atrevidamente en ejercer como intermediario en la resolución de la cuestión romana ${ }^{32}$, y acabó entonando un desafortunado discurso público en el que, apelando al espíritu de cruzada, se presentaba como patrón de la Iglesia en Hispanoamérica ${ }^{33}$. Cuando en abril de 1931 Alfonso XIII abandonó Madrid, el nuncio expresó ante la Secretaría de Estado la responsabilidad de un monarca que había demostrado una manifiesta incapacidad para los asuntos de gobierno. En marzo de 1932, cuando las noticias de la campaña orquestada por el rey contra el nuncio llegaron a sus oídos, Tedeschini estalló de ira y mostró por escrito su indignación ante Pacelli, exponiendo una torrencial catarata de denuncias contra el monarca derrocado ${ }^{34}$. En esas fechas, la Secretaría de Estado había ya establecido un canal de comunicación alternativo y permanente con la familia real en el exilio, a través de los informes enviados por el nuncio en París, Luigi Maglione ${ }^{35}$.

\section{LA CLAVE CLERICAL. EL PODER DE UNA BIRRETA}

Entre las instrucciones que el nuncio recibió en abril de 1921 desde las diversas congregaciones de la curia romana sobresalen las alusiones a un clero español con formación deficiente y escasa actividad misionera ${ }^{36}$. Las gestiones

en los Seminarios de Almería y Roma. Operario de la casa profesa de Madrid desde 1912, influyó de manera determinante en la erección del monumento del Sagrado Corazón de Jesús en el Cerro de los Ángeles, inaugurado en mayo de 1919 por Alfonso XIII. Director espiritual de la madre Maravillas de Jesús y director de la Congregación de Caballeros del Pilar. Sus lecciones sacras eran publicadas semanalmente por el diario integrista El Siglo Futuro. Desde 1927 pasó a dirigir la casa de los jesuitas en Madrid y durante los años de la República residió en la iglesia del Gesù de Roma.

32 Informe del nuncio a Pietro Gasparri (26 de octubre de 1923). AAEESS, Spagna IV, fascículo 60: 39-42.

33 Informe del nuncio en Buenos Aires, Giovanni Beda, sobre el conflicto ocasionado en Argentina por el discurso del Rey Alfonso XIII (octubre de 1923). AAEESS, Spagna IV, fascículo 60: p. 72.

34 Informe del nuncio a Pacelli sobre los ataques del conde Rodríguez de San Pedro contra su persona (25 de marzo de 1932). ASV, ANM, Caja 892: 200-223.

35 Informe de la visita efectuada por el nuncio en París al rey Alfonso XIII (18 de abril de 1931), AAEESS, Spagna IV, Fascículo 117: pp. 74 a 75.

36 Instrucciones de la Sagrada Congregación de Seminarios y Estudios Universitarios. ASV, ANM, Caja 778: 209-210; Instrucciones al nuncio de la Sagrada Congregación 
realizadas para lograr la adecuación a las exigencias marcadas desde Roma fueron significativamente intensas, pero se vieron muy condicionadas por los ciclos de cambio observados tanto en Madrid como en Roma.

La provisión episcopal de las diócesis durante la gestión del nuncio distingue tres etapas marcadamente diferenciadas, en función de las coyunturas políticas y de las menores o mayores facultades establecidas canónicamente para la designación de prelados. En los primeros ańos se observa un ascenso de los obispos apoyados por movimientos regionalistas, aupados por los designios del patronato en el que la familia real o los diversos Gobiernos intervienen para satisfacer a las élites emergentes en cada lugar. Desde la toma del poder por Primo de Rivera, se aprecia la tendencia opuesta, con un Gobierno y un monarca obsesionados en eliminar cualquier resquicio hipotético de separatismo. Al tiempo, el mismo nuncio que en marzo de 1924 había celebrado como triunfo propio la constitución de la Junta Delegada del Real Patronato Eclesiástico, autorizada por el Gobierno de Primo, trasmitiría en marzo de 1930 el temor de su posible disolución, tras las denuncias de un monarca que consideraba aquel organismo un severo ataque a sus tradicionales prerrogativas. Paradójicamente, la proclamación de la II República y las circunstancias de carácter excepcional atravesadas por la Iglesia española, otorgaron a Tedeschini mayor capacidad que la que había tenido nunca antes, inclinando decisivamente la balanza de los nuevos nombramientos eclesiásticos, temporales o definitivos, en favor de sus orientaciones ${ }^{37}$. Sin embargo, como pronto descubriría, sus decisiones no siempre serían las más acertadas para sus intereses.

Para una curia romana preocupada por un clero diocesano que mostraba signos de difícil acomodación a los nuevos tiempos ${ }^{38}$, las congregaciones religiosas eran apreciadas como la herramienta clave que podría permitir la necesaria transformación de la Iglesia española. Sin embargo, aunque su presencia cuantitativa y cualitativa se había incrementado notablemente en las décadas previas, sus actividades seguían marcadas en la mayor parte de los casos por los moldes tradicionales. Impulsar la actividad misionera y la acción social se convirtió así en uno de los principales objetivos del nuncio que se valió del impulso de algunas órdenes como los salesianos, los paúles o los claretianos, preferidos frente a la poderosa congragación franciscana que seguía

de Propaganda de la Fe (20 de mayo de 1921). ASV, ANM, Caja 778: 211-212. Véase también Cárcel (1999).

37 Nota de la Secretaría de Estado al nuncio (11 de julio de 1931). ASV, ANM, Caja 892: p. 4.

38 Cárcel (2006). 
manifestándose como férreo pilar del frente integrista. Junto a ellos, pero no siempre con ellos, los jesuitas incrementaron su influencia en el cuidado de las élites y las oligarquías regionales. Habían quedado atrás los aires de renovación auspiciados entre 1906 y 1914 por el superior general Franz Wernz, acusado entonces de conciliar con las tesis modernistas. Las tesis proclives al integrismo avaladas por Wlodimir Ledochowsky, aristócrata educado entre los jesuitas de Cracovia y que ejerció como superior general desde febrero de 1915, imprimieron un nuevo rumbo a la congregación, tejiendo redes con las principales familias de la nobleza y la realeza europeas. La jerarquía y la disciplina propias de la orden ignaciana se ponían entonces al servicio de la lucha contra el protestantismo, el laicismo y el comunismo. Benedicto XV se mostró algo más distante frente a los intereses de la Compañía de Jesús ${ }^{39}$, pero Pío XI convirtió de nuevo a la institución ignaciana en brazo derecho de la política papal. En España, Miguel Primo de Rivera, antiguo alumno de los jesuitas, colocó de nuevo a la congregación en una posición aventajada, centro de la diana de la futura espiral republicana.

Tedeschini debió aguardar mucho tiempo por una birreta cardenalicia de la que se había venido hablando ya antes de su llegada a España. Mientras tanto, los cardenales designados durante el pontificado de Della Chiesa fueron marginados o mandados provisionalmente al ostracismo tras el ascenso de Aquille Ratti ${ }^{40}$. Tres de los cuatro cardenales españoles designados por Pío XI ejercieron a su vez como arzobispos de Toledo, primados de España y directores pontificios de la Acción Católica ${ }^{41}$. Si las relaciones con Enrique Reig Casanova fueron por lo general sosegadas, no ocurriría lo mismo con Pedro Segura y con Isidro Gomá, que marcaron muy pronto distancias con Tedeschini tras haber obtenido la birreta roja. Ambos, valiéndose del trato de confianza con

39 Benedicto XV deseaba formar un clero diocesano con espíritu misionero alejado del control de los jesuitas, por lo que promocionó la fundación del Seminario de Misiones de Burgos regido por el cardenal Benlloch, que pretendía competir con las promociones formadas en la Universidad de Comillas. El mismo papa había frenado las aspiraciones de la congregación de San Ignacio para fundar un seminario en Madrid. Informe de la Sagrada Congregación de Seminarios y Estudios Universitarios (abril de 1921). ASV, ANM, Caja 778: 209-210.

40 A Juan Soldevilla Romero, cardenal desde diciembre de 1919, asesinado en junio de 1923 por el grupo anarquista Los Solidarios, se suman Benlloch y Vivó y Vidal y Barraquer, arzobispos de Burgos y Tarragona respectivamente, y cardenales desde el consistorio de marzo de 1921.

41 El cuarto fue Vicente Casanova y Marzol (1854-1930), arzobispo de Granada, cardenal desde marzo de 1925. 
Pío XI, mantuvieron férreas discrepancias con un nuncio debilitado por su lejanía respecto a la curia y privado durante mucho tiempo de honores y prerrogativas asociadas al título de cardenal. En octubre de 1927 el nuncio había avalado con fervor la promoción de Pedro Segura como garantía de futuro para la Iglesia española ${ }^{42}$, pero en enero de 1929 alertaba ya sobre la peligrosa deriva del cardenal ${ }^{43}$, un cambio de postura similar a lo acontecido ańos antes respecto al obispo de Madrid Leopoldo Eijo Garay ${ }^{44}$, o años más tarde respecto al cardenal Isidro Gomá, arropado inicialmente por el nuncio ${ }^{45}$ y convertido en su más poderoso enemigo desde diciembre de $1935^{46}$. Los proyectos y los intereses de Tedeschini encontraron férrea resistencia por muchos de aquellos que él había ayudado a promocionar. Sin embargo, mantuvo alianzas más firmes con los metropolitanos que no habían sido designados durante el pontificado de Pío XI, como el arzobispo Gandásegui en Valladolid y el cardenal Ilundain en Sevilla, convertidos en baluartes para avanzar en sus políticas, o su antiguo enemigo, el cardenal Vidal, su mayor aliado en la tesitura republicana.

\section{LA CLAVE SOCIAL. POCOS Y MAL AVENIDOS}

Entre las instrucciones que el nuncio recibió en abril de 1921 antes de partir a su destino sobresalió también la necesidad de extender una acción social más amplia que la escasamente desplegada hasta esas fechas por los católicos españoles, divididos por agrias disputas políticas, cuando no por el ansiado protagonismo de determinados notables de la aristocracia o de la burguesía emergente ${ }^{47}$. El prólogo de la llegada de Tedeschini a España había tenido lugar durante la última de aquellas batallas. En mayo de 1919 el acto

42 Informe de nuncio a Pietro Gasparri (27 de octubre de 1927). AAEESS, Spagna IV, Fascículo 87: 86-87. Sobre la trayectoria del cardenal Segura, véase Martínez Sánchez (2004).

43 Informe del Nuncio a Gasparri (20 de enero de 1929). ASV, ANM, Caja 881: 23-45.

44 Rodríguez (2012b).

45 «Informe del nuncio ante la Secretaría de Estado de la solicitud de Isidro Gomá, obispo de Tarazona, para presentar su candidatura a Cortes en la provincia de Tarragona (1 de junio de 1931). AAEESS, Spagna IV, Fascículo 118: 3-9. Sobre la trayectoria del cardenal Gomá, véase Dionisio (2011).

46 Informe del nuncio a Giuseppe Pizzardo sobre los conflictos suscitados por la primacía de Toledo (5 de abril de 1936). ASV, ANM, Caja 956: 312.

47 Instrucciones al nuncio de Sagrada Congregación Consistorial (30 de abril de 1921). ASV, ANM, Caja 778: 203-204 (Cárcel, 1990). 
de consagración nacional de España ante el Sagrado Corazón de Jesús había exhibido con orgullo el triunfo de una Espańa aislada de las tormentas que acosaban el continente. Sin embargo, en julio de ese mismo año un grupo de intelectuales inspirados por el aperturismo de Benedicto XV y por iniciativas similares a las alentadas por entonces en Europa y América, quebró ese discurso triunfalista. Su manifiesto, atrevidamente denominado de la "Democracia Cristiana", presentaba un carácter innovador por muy diversas razones $^{48}$. La más destacada de todas ellas es que se sentía legitimado para expresarse públicamente en nombre de los católicos sin contar con el permiso oficial previo de la jerarquía o de alguno de sus patronos más destacados. El monarca, los obispos o el nuncio Ragonesi ni siquiera aparecían citados en tal declaración. Entre sus firmantes había clérigos, pero en su mayor parte eran seglares reconocidos de la vida social y cultural, católicos militantes que parecían sentirse lo suficientemente adultos y libres como para manifestar sin permiso expreso de las autoridades sus preocupaciones y anhelos. Esgrimían, además, un discurso de apertura a la modernidad y presentaban los retos que debían asumir como ciudadanos católicos en la coyuntura de posguerra. Aquella declaración suscitó de manera inmediata una dura réplica por parte del frente integrista y el director del diario El Siglo Futuro, Manuel Senante, se convirtió en ariete de una cruda batalla, que contó en Roma con el apoyo de los jesuitas y el beneplácito del Tribunal del Santo Oficio dirigido por Merry del Val.

En septiembre de 1920 el fallecimiento del cardenal Guisasola supuso un duro golpe para los osados partidarios de la Democracia Cristiana. El arzobispo de Sevilla, Enrique Almaraz y Santos, pareció a ojos de Benedicto XV el más adecuado para serenar las aguas turbulentas del enfrentamiento. El 15 de noviembre fue promocionado como arzobispo de Toledo, pero debió aguardar todavía algunos meses para tomar posesión definitiva de la sede primada. Unos meses de interregno que resultaron decisivos ${ }^{49}$. El 8 de marzo de 1921, Eduardo Dato, presidente del Gobierno y líder del Partido Conservador, fue asesinado en un atentado terrorista perpetrado en la madrileńa Puerta de Alcalá. Dos días más tarde, bajo la consternación del luto nacional, la Junta de Metropolitanos se reunía por primera vez en su historia y acordaba emitir una condena sobre el grupo de la Democracia Cristiana; al día siguiente Almaraz presidía como cardenal primado el entierro del llorado presidente.

48 Memoria del proyecto de estatutos presentados por Severino Aznar al nuncio Francesco Ragonesi (28 de julio de 1919). ASV, ANM, Caja 959: 672-690.

49 Informe de Severino Aznar al nuncio Francesco Ragonesi (5 de marzo de 1921). ASV, ANM, Caja 957: 691-704. 
La llegada de Tedeschini a Madrid reavivaría las esperanzas de los condenados al silencio solo unos meses antes ${ }^{50}$. El 2 de julio Severino Aznar solicitó una audiencia ante el nuevo nuncio. Al día siguiente, hizo su entrada solemne en la catedral de Toledo el nuevo primado de España. Durante ese verano Tedeschini labró un terreno más propicio para la siempre pendiente y lastimosa cuestión de la acción social. El 1 de octubre presentó una significativa declaración de intenciones en la meca del integrismo. Su discurso ante el claustro de la Universidad de Comillas presentaba una diáfana apelación a la necesidad de incrementar la acción social-católica. En esas fechas, mientras la Democracia Cristiana restañaba sus heridas, Ángel Herrera soñaba ya con una gran campaña social, similar a las acometidas dos ańos antes por la National Catholic Welfare Conference en los Estados Unidos o por la Unión Popular Católica en Argentina. El 5 de noviembre el nuncio se reunió con los principales dirigentes de Democracia Cristiana pareciendo dar carta de naturaleza a su rehabilitación definitiva ${ }^{51}$. Solo dos meses más tarde, el fallecimiento del papa Della Chiesa y la coronación de Aquille Ratti frustrarían los planes previstos. Cuando en diciembre de 1922 los dirigentes de Democracia Cristiana fundaron el Partido Social Popular, hacía algún tiempo que la jerarquía vaticana había optado por abandonar a su suerte la hipótesis de la participación católica en el juego parlamentario ${ }^{52}$. La marcha sobre Roma de Mussolini había iniciado el camino del fascismo clerical y el posterior golpe militar de Primo fraguaría la tesis de una dictadura de regeneración nacional anclada en drásticos parámetros confesionales.

Si Tedeschini mostró admiración por alguno de los españoles que conoció durante su estancia en Madrid, fue sin duda por Ángel Herrera. La opinión del director de El Debate resultó trascendental desde un primer momento, no solo porque este diario se convirtió en órgano de referencia para la conformación de una determinada imagen de España, sino por los diversos proyectos que aquel incansable emprendedor de obras católicas le fue presentando una y otra vez, y la constancia y la eficiencia que manifestó para ejecutarlos sin estridencias. Por obra y gracia de Herrera, de su diario y de sus activos propagandistas, el nuncio pudo contar desde septiembre de 1921 con una plataforma

50 Escrito firmado por los obispos de España sobre el grupo de la Democracia Cristiana (marzo de 1921). ASV, ANM, Caja 957: 9-21.

51 Informe del nuncio a la Secretaría de Estado sobre la reunión mantenida el día 5 de noviembre con el grupo Democracia Cristiana (11 de noviembre de 1921). ASV, ANM, Caja 957: 27-31.

52 La relación epistolar mantenida entre Luigi Sturzo y los partidarios de Democracia Cristiana en España en las décadas siguientes es abordada con gran detalle en Botti (2012). 
para extender su ansiado proyecto de Juventudes Católicas, a través de la Confederación de Estudiantes Católicos ${ }^{53}$, selecto caldo de cultivo de toda una generación de militantes. Su gestión confidencial con el ministro de Educación permitió además exhibir la hegemonía de esta organización estudiantil en años en los que la consagración de santo Tomás como patrono de las universidades se convirtió en símbolo de restauración de las posiciones eclesiales en el ámbito académico. Todo ello animó al nuncio a arropar el proyecto diseńado por Herrera para acometer una gran semana social-católica, bendecida con la audiencia privada ante Benedicto XV, la última de las concedidas por el pontífice $^{54}$. Las cartas cursadas desde la nunciatura reflejan la preocupación de Tedeschini por ajustarse a los posibles vientos de cambio que pudiesen agitar la curia $^{55}$. Solo una semanas más tarde, tras las mutaciones observadas en la sede pontificia, la oposición furibunda del monarca y de los jesuitas que inspiraban a este, y el malestar de las principales familias de la aristocracia, exasperadas por la penetración en la católica España de una estrategia pastoral «a la americana», provocaron el acoso y derribo de aquella campaña a escasos días de su puesta en práctica. El 31 de marzo el episcopado suspendió públicamente el proyecto. La travesía del publicista católico Luigi Daniel y del obispo argentino Miguel De Andrea, llegados a Madrid para arropar la iniciativa, ganaría el aprecio popular, pero contaría con la animadversión de las principales autoridades políticas y eclesiásticas, que consideraban a aquellos foráneos llegados del otro lado del océano atrevidos polizones en un navío anclado por la tradición ${ }^{56}$.

Tedeschini afirmó siempre defender los intereses del Vaticano frente a las inoportunas injerencias de unas oligarquías escasamente preocupadas por el bien de la Iglesia y de sus almas, y de las que poco podía esperarse más que la defensa

53 Informe de Ángel Herrera al nuncio tras la VIII Asamblea de la Asociación Católica de Propagandistas (15 de septiembre de 1921). ASV, ANM, Caja 881: 264-268.

54 Cartas de presentación del nuncio de Ángel Herrera y Luigi Daniel ante el sustituto de la Secretaría de Estado, Mons. Pizzardo, y el maestro de cámara de Su Santidad, Caccia Dominione (10 de enero de 1922). AAEESS, Spagna IV, Fascículo 32: 52-53.

55 Las noticias de la enfermedad de Benedicto XV llegaron unos días antes de su fallecimiento, ocurrido el 22 de enero de 1922. Esa misma mañana el diario El Imparcial aludía a la estrecha relación entre el cardenal primado Almaraz y el pontífice, que habían fraguado su amistad durante la estancia de este último en la nunciatura de Madrid. El 23 de enero el diario La Acción publica el fallecimiento de ambos eclesiásticos.

56 Informe del nuncio sobre la oposición del rey a la campaña (12 de abril de 1922). AAEESS, Spagna IV, Fascículo 32: 75-76. 
de sus privados intereses. Los conflictos mantenidos con algunas de las principales familias de la nobleza española pueden apreciarse en su tempestiva relación con el duque de $\mathrm{Alba}^{57}$, el marqués de Luca de Tena, propietario del diario $A B C$, el conde de Irujo o el conde Rodríguez de San Pedro, designado por el cardenal Segura presidente de Acción Católica en febrero de 1929 e incesante promotor de las intrigas contra el nuncio desde su posterior exilio romano ${ }^{58}$.

El único ámbito de acción social en el que los católicos ostentaban cierta hegemonía cuando Tedeschini llegó a España era el del sindicalismo agrario, pero la Confederación Nacional Católica Agraria (CONCA), fundada en 1917 por Antonio Monedero, se vio pronto sacudida por la guerra interna desatada entre sus dirigentes. El apoyo del jesuita Sisinio Nevares a los propagandistas permitió que en noviembre de 1921 una nueva directiva se encaramase en la cúpula de la organización. Desde ese mismo día, la resistencia numantina enarbolada por el fundador, alimentó una cruenta batalla por hacerse con el control de un sindicalismo agrario cada vez más dividido entre la CONCA, la Liga Nacional de Campesinos y diversas asociaciones de carácter regional ${ }^{59}$. Las disputas entre los partidarios del antiguo líder y los nuevos dirigentes desangraron durante años el sindicalismo católico. Solo las urgencias del contexto republicano posibilitaron un reencuentro que llegó demasiado tarde. Una vez más, Tedeschini confió en Ángel Herrera como factótum de esa operación de ingeniería institucional que requería de tantas dosis de conocimiento como de tacto.

\section{LA CLAVE POLÍTICA. EXTRAÑOS ALIADOS Y ENEMIGOS ÍNTIMOS}

Los primeros meses de Tedeschini en España habían estado marcados por una creciente inestabilidad política y social por la que el nuncio mostró preocupación en innumerables ocasiones ${ }^{60}$. Asesinado Eduardo Dato, Antonio Maura parecía ser el único dirigente que contaba con cierto aprecio por

57 Informe del nuncio (31 de enero de 1930). ASV, ANM, caja 831, pp. 533 a 536. Informe del nuncio a la Secretaría de Estado (24 de enero de 1934). AAEESS, Spagna IV, Fascículo 180: 68-72.

58 Informe del nuncio a Pacelli sobre los ataques a su persona (9 de marzo de 1932). ASV, ANM, Caja 892: 226-232.

59 Carta de Antonio Monedero al nuncio Tedeschini (13 de octubre de 1925). ASV, ANM, Caja 888: 148-149.

60 Informe del nuncio a la Secretaría de Estado. Sobre el nuevo Gobierno (9 de diciembre de 1922). ASV, ANM, Caja 831: 143-144. 
parte de Tedeschini, pero los sucesos de Marruecos y las diversas disputas generadas por las Juntas Militares le llevaron también a seguir con atención la acción desplegada por el general Millán Astray ${ }^{61}$. Mantuvo, sin embargo, una posición inicial distante respecto al general Primo de Rivera, que pronto se haría con su confianza. El dictador, por encima de su discutible moral privada, se ganó el aprecio del nuncio por una labor de gobierno que, a ojos del delegado pontificio, había instaurado un régimen de orden social y económico, regenerando la vida pública y otorgando importantes concesiones a la Iglesia ${ }^{62}$. El general había respondido mejor a las demandas y los intereses eclesiales que el jefe de la dinastía borbónica, siempre tan voluble ante las circunstancias políticas, y tan inflexible frente a la Iglesia. Por todos esos motivos, Tedeschini mostró su plena consternación cuando Primo decidió abandonar el Gobierno. Según sus palabras, su renuncia dejaba el país en un estado de peligrosa inestabilidad, más grave y alarmante que la reinante en los primeros meses de su periplo por España ${ }^{63}$.

La caída del dictador y el ascenso de Pacelli a la Secretaría de Estado inauguraron un nuevo tiempo, no solo en el ámbito político, sino también en el eclesial. En función de su experiencia previa en Baviera y de los informes elaborados por eclesiásticos de su plena confianza, como el afamado jesuita y musicólogo vasco, José María Nemesio Otaño, o el arcipreste de la catedral de Girona, Antonio Vilaplana Forcada, la Secretaría de Estado aconsejó desde marzo de 1930 una cauta adecuación de las formas y las estrategias a una previsible proclamación de la República ${ }^{64}$. Sin embargo, Tedeschini siguió sońando durante un tiempo con un posible éxito del proyecto inspirado por la Unión Monárquica Nacional y los admiradores del orden construido por Primo ${ }^{65}$. A su escasa convicción por el giro estratégico pacelliano se sumaban

61 Informes del nuncio a Secretaría de Estado (12 y 26 de noviembre de 1922), ASV, ANM, caja 831: 125-127 y 131-135.

62 Las relaciones entre la Iglesia y la dictadura a la luz de los boletines eclesiásticos fueron analizadas en Adagio (2004). Martínez Álvarez (2015) ha plasmado recientemente la visión de Tedeschini respecto al régimen y sus gestiones ante el dictador.

63 Informe del nuncio a la Secretaría de Estado (22 de febrero de 1930). ASV, ANM, caja 831: 574-576.

64 Nota de la Secretaría de Estado al nuncio (4 de marzo de 1930). ASV, ANM, caja 831, pp. 539-540. Los primeros informes presentados por José María Nemesio Otaño (12 y 20 de febrero de 1931) y Antonio Vilaplana Forcada (30 de noviembre de 1930). ASV, AAEESS, Spagna IV, Fascículo 105: 35- 51 y 70-77.

65 Informe del nuncio a la Secretaría de Estado (26 de marzo de 1930). ASV, ANM, Caja 831: 591-592. 
las enormes dificultades para implantar esa nueva orientación entre un episcopado forjado en las tesis del integrismo. No en vano, en febrero de 1929 Tedeschini había mostrado ya ante Gasparri su preocupación por la inquietante deriva del cardenal Segura y sus aliados. Ahora, advertía directamente a Pacelli de los enormes obstáculos que deberían salvarse para aplicar una estrategia conciliadora con un cardenal primado y una buena parte del episcopado convencidos de las bondades del integrismo. Mientras tanto, las apelaciones de la Secretaría de Estado para que el cardenal Segura rebajase la dosis de la receta integrista solo parecieron provocar su radicalización, alimentada por su enemistad con Tedeschini y su relación de confianza con Pío XI.

Proclamada la República, alejar a Segura de la arena política, al menos temporalmente, resultaba imprescindible para desarrollar el proyecto conciliador avalado por la Secretaría de Estado. El denostado Vidal se convertiría por santo y seña de Pacelli en ariete de una estrategia negociadora que otorgaría tiempo para la reconstrucción del frente eclesial ${ }^{66}$. Entre abril y noviembre de 1931 el Vaticano trabajó así afanosamente por alcanzar un acuerdo satisfactorio con el régimen republicano. Ni los sucesos incendiarios de mayo, ni los resultados electorales de junio truncaron tales esperanzas. Ni siquiera la salida del Gobierno de Miguel Maura y de Alcalá Zamora el 14 de octubre de 1931 frustraron unas expectativas que se mantuvieron vigentes hasta los días previos a la aprobación definitiva del texto constitucional. Hasta ese momento, los hombres de confianza de Pacelli en Madrid, Barcelona, Roma, París, Múnich o Washington, siguieron afirmando que, pese a las muchas dificultades, podría llegarse a un acuerdo final que salvaguardase los intereses eclesiales más preciados. Los informes de Ángel Herrera, del cardenal Vidal, del jesuita Nemesio Otaño o del diplomático estadounidense William F. Montavon, enviado a España por la National Catholic Welfare Conference, así lo constatan ${ }^{67}$.

Tedeschini — muy a su pesar-, se había convertido en clave de bóveda de la estrategia posibilista, y las embestidas contra él arreciaban no solo desde las diversas diócesis españolas, sino, sobre todo, desde París y desde Roma,

66 Sobre la historiografía referente a la cuestión eclesial durante la II República, Rodríguez (2013) y Cueva y Montero (2009).

67 Carta enviada desde el Hotel Palace de Madrid por William Montavon a John J. Burke, secretario general de la National Catholic Welfare Conference, Washington D. C. (20 de octubre de 1931). William Montavon Papers, Box 2, Folder 10. American Catholic History Research Center. Catholic University of America (CUA). Sobre las relaciones entre el episcopado estadounidense y los católicos espańoles en ese período véase Rodríguez (2016). 
donde las acciones de los partidarios del monarca y del cardenal exiliados suponían una afrenta continua a su toma de decisiones. La aprobación del texto constitucional suscitó la primera marejada por parte del frente integrista ${ }^{68}$, y la clausura posterior de los colegios jesuitas incrementó el número de acérrimos opositores a un nuncio, forzado a confesar su desesperación ante su viejo amigo, Eugenio Pacelli ${ }^{69}$. Tedeschini siempre mostró escasa fe en la capacidad de Niceto Alcalá Zamora, a quien tildaba como un católico tibio y liberal incapaz de serenar el espíritu de aquella revolución republicana, pero fijó muy pronto su atención en Alejandro Lerroux, el único líder que podría sosegar el fervor anticlerical que tanto había excitado en otros tiempos ${ }^{70}$. Ambos dirigentes contaron, sin embargo, con la confianza expresa del cardenal Vidal, que a través de sus emisarios ante la Secretaría de Estado orientaba una política apaciguadora que el nuncio se veía obligado a seguir por disposición de Pacelli.

La nueva Acción Católica, reconstruida de la nada según palabras del propio nuncio, requería de autonomía frente a las peligrosas banderas del partidismo. Mientras Herrera y Tedeschini se ocupaban de la conformación del movimiento confesional, el 14 de enero de 1933, José María Gil Robles mantuvo una reunión confidencial en las dependencias de la Secretaria de Estado con Giuseppe Pizzardo, mano derecha de Pacelli en la sigilosa política vaticana. El futuro ministro de Guerra del gobierno de Lerroux aludía a la difícil situación del nuncio, acosado por los diversos frentes de batalla del catolicismo, y abogaba por la conquista legal de una República para los católicos ${ }^{71}$. El triunfo electoral cosechado en las elecciones de noviembre de ese mismo año pareció otorgar credibilidad a esa hipótesis y los dirigentes de la CEDA optaron por adoptar una posición de cautela que siguiese haciendo crecer aquella imparable marea católica. El apoyo prestado temporalmente a Lerroux podría servir para moderar el furor anticlerical y ganar el tiempo necesario para reconstruir una alternativa hegemónica, liderada por un Gil Robles todavía demasiado joven e inexperto como para hacerse con las riendas del

68 Informe del nuncio a la Secretaría de Estado (22 de diciembre de 1931). AAEESS, Spagna IV, Fascículo 177: 37- 39.

69 Carta del nuncio a Eugenio Pacelli (25 de marzo de 1932). ASV, ANM, Caja 892: 200-223.

70 Sobre la trayectoria política inicial de Lerroux, sigue resultando imprescindible Álvarez (2011).

71 Informe entregado por José María Gil Robles a José Pizzardo en Roma (16 de enero de 1933). AAEESS, Spagna IV, Fascículo 177: 65-77. 
Estado $^{72}$. Una negociación que implantase medidas duraderas para los intereses eclesiásticos exigía además de un liderazgo fuerte y un apoyo parlamentario estable y ninguno de los siguientes jefes del Ejecutivo contaría con tal aval. A juicio del nuncio, la extrema división de las Cortes hacía de los Gobiernos títeres de los giros que podían existir en los encuentros y desencuentros de la dinámica parlamentaria.

Mientras tanto, lejos de rebajar sus demandas, el frente integrista se mantuvo intransigente y escaló posiciones en Roma, catapultado por los recursos financieros de algunos notables y por un contexto internacional en el que los Estados autoritarios cobraron protagonismo. En marzo de 1933, el Portugal de Salazar aprobó una Constitución que daba carta de naturaleza al denominado Estado Novo, mientras el canciller Dollfuss disolvía el Parlamento en Austria e iniciaba una dictadura parapetada por el discurso del nacional catolicismo. En agosto de 1934 Hitler declaraba definitivamente enterrada la República de Weimar inaugurando el III Reich. Incluso al otro lado del Atlántico, en las repúblicas americanas, el autoritarismo sin complejos parecía favorecer los intereses eclesiásticos. En octubre de 1934, mientras Gil Robles sofocaba como ministro de la Guerra el estallido revolucionario desatado en Asturias, en la otra orilla del océano, el arzobispo Gomá contemplaba con beneplácito cómo la República Argentina manifestaba triunfalmente la toma del espacio público por unas masas católicas amparadas por un Estado de tintes autoritarios que combinaba los valores castrenses y las tradiciones sagradas ${ }^{73}$.

También en España la Iglesia apostaría por la reconquista del Estado, republicano o no, eso era lo de menos, por las vías electorales o por otros medios, si estos se estimaban necesarios para satisfacer sus intereses. En esta tesitura, la fuerte oposición interior y exterior y la coyuntura internacional no invitaban a alcanzar un tratado de modus vivendi con un Gobierno que, liderado por un Partido Radical en descomposición, no parecía garantizar la estabilidad requerida para el proyecto de restauración eclesial. Como ahora sabemos, la carta electoral de la CEDA fracasó en febrero de 1936, pero ya antes de esa decisiva cita, Pío XI y Pacelli habían tomado la decisión de sustituir a las figuras clave del complicado tablero de ajedrez eclesiástico en España. La sustitución del cardenal Vidal y de Ángel Herrera por el cardenal Isidro

\footnotetext{
72 Informe confidencial sobre la situación política en España elaborado para la Secretaría de Estado del Vaticano por Alberto Martín Artajo, letrado del Consejo de Estado y secretario personal de Ángel Herrera (agosto de 1934). AAEESS, Spagna IV, Fascículo 220: 89-123.

73 Zanatta (1996).
} 
Gomá, que por decisión pontificia sumaría a la primacía episcopal la dirección de la Acción Católica desde diciembre de 1935, eran la mejor prueba de ello.

Tras la victoria del Frente Popular, Tedeschini mantuvo una consideración positiva sobre la subida al Gobierno de Manuel Azańa. El denostado enemigo del bienio republicano resultaba ahora necesario para proteger los intereses de la Iglesia frente a los exaltados cánticos que amenazaban con una hipotética revolución que ya no solo afectaría a las conciencias. Cuando solo unos días más tarde fue informado de su definitivo retorno a Roma, el nuncio ofreció un último balance de su gestión ante la Secretaría de Estado denunciando los manejos de sus opositores integristas. La conformación de una prensa católica eficaz, la expansión de las Juventudes Católicas y la organización de una verdadera Acción Católica eran los principales avales de su travesía. Una vez más, las empresas encomendadas a Ángel Herrera, que por aquel entonces iniciaba su carrera sacerdotal en Friburgo, servían como escaparate de su travesía en Espańa, pero Tedeschini trasmitía a su vez su hondo pesar por el incierto futuro de todas aquellas obras, puestas en entredicho en manos de los nuevos dirigentes eclesiales ${ }^{74}$. El 4 de junio de 1936, el Vaticano designó un nuevo nuncio en la figura de Filippo Cortesi. El siciliano contaba ya con un exitoso aval diplomático como delegado pontificio en las repúblicas de Venezuela y Argentina, donde hacía algunos años que los militares se habían adueñado del espacio político. Solo unas semanas más tarde, el golpe militar fallido y el inicio de la guerra darían paso a un nuevo y más trágico tiempo ${ }^{75}$.

\section{CONCLUSIÓN}

La trayectoria vital de Federico Tedeschini en la nunciatura de Madrid permite apreciar como su interpretación de los acontecimientos y su toma de

74 Sobre el acto de reparación y desagravio orquestado por Ángel Herrera hacia Tedeschini algunos años más tarde, véase Herrera (1949). Sobre las posiciones mantenidas por Tedeschini durante la Guerra Civil española en las reuniones plenarias de la Congregación de Asuntos Eclesiásticos Extraordinarios, véase Cárcel (2008).

75 El inicio de la Guerra Civil impedirían que Cortesi llegase a su destino y el 24 de diciembre ejercería un nuevo encargo como nuncio Apostólico en Polonia. Mientras tanto, desde el 11 de junio al 4 de noviembre, el auditor Silvio Sericano serviría como encargado de negocios interino de la Nunciatura. Habría que aguardar al 16 de mayo de 1938 para que el Vaticano designase un nuevo nuncio apostólico en España (Rodríguez, 2017). 
decisiones se vio condicionada no solo por los sucesos acaecidos en la España de aquellos años, sino también y de manera muy destacada por el trascendental juego de intereses y disputas entre las diversas tendencias existentes en el seno de la curia vaticana en la Europa de entreguerras. La curia en la que había emergido como favorito de Benedicto XV, el giro apreciable durante el pontificado de Pío XI, el ascenso de Pacelli a la Secretaría de Estado, o las sigilosas maniobras de su lugarteniente Giuseppe Pizzardo, marcarían las actuaciones del nuncio tanto o más que los convulsos cambios observables en la trayectoria política española. Interpretar las acciones del delegado pontificio en España durante tres agitados lustros, exige adoptar una perspectiva atenta a la dimensión global de la corporación eclesiástica y a las dinámicas internas de la propia institución en España y fuera de ella. Las respuestas ofrecidas por la nunciatura ante los cambios sociales y políticos generados durante los diversos Gobiernos de la monarquía y del régimen republicano deben interpretarse a la luz de todo ello, y el análisis de la bibliografía publicada al efecto y de la voluminosa documentación consultable sobre la particular odisea española de Tedeschini ofrecen claves valiosas en las que conviene seguir indagando.

\section{Bibliografía}

Adagio, C. (2004). Chiesa e nazione in Spagna. La Ditttatura di Primo de Rivera (1923-1930). Milano: Unicopli.

Álvarez Junco, J. (2011). El emperador del Paralelo. Barcelona: RBA.

Botti, A. (2012). Luigi Sturzo e gli amici spagnoli. Carteggi (1924-1951). Soveria Mannelli: Rubbetino Editore.

— Montero, F. y Quiroga, A. (eds.) (2013). Católicos y patriotas. Religión y nación en la Europa de entreguerras. Madrid: Sílex.

Cárcel Ortí, V. (1990). Benedicto XV y el catolicismo social español. Analecta Sacra Tarraconensia, 63, 7-152.

- (1999). Instrucciones del cardenal Gasparri al nuncio Tedeschini en 1921. Revista Española de Derecho Canónico, 41, 455-482.

(2005). Benedicto XV y la crisis política en España. Despachos políticos del nuncio Ragonessi. Archivum Historiae Pontificiae, 43, 157-261.

- (2006). Informe de la visita apostólica a los Seminarios españoles de 1933/34. Salamanca: Sígueme.

- (2007a). La nunciatura de Federico Tedeschini en Madrid durante la monarquía (19211931). Archivum Historiae Pontificiae, 45, 97-183.

(2007b). Documentos inéditos del pontificado de Pío XI sobre España (1922-1939). Analecta Sacra Tarraconensia, 80, 231-496.

- (2008). Pío XI entre la República y Franco. Madrid: BAC. 
Cueva, J. y Montero, F. (2009). Laicismo y catolicismo. El conflicto político-religioso en la Segunda República. Alcalá de Henares: Universidad de Alcalá.

Dionisio Vivas, M. A. (2011). Isidro Gomá ante la dictadura y la república. Pensamiento político-religioso y acción pastoral. Toledo: Instituto Teológico de San Ildefonso.

Dolan, J. P. (2002). In search of an American Catholicism. A history of religion and culture in tension. New York: Oxford University Press. Disponible en: https://doi.org/10.1093/0 195069269.001.0001.

Fattorini, E. (1992). Germania e santa Sede. Le nunziature di Pacelli tra la Grande Guerra e la Reppublica di Weimar. Bologna: Il Mulino.

- (2007). Pio XI, Hitler e Mussolini. La solitudine di un papa. Torino: Eiunadi.

- (ed.) (2013). Diplomazia senza eserciti. La relazioni internazionali della Chiesa di Pio $X I$. Roma: Carocci Editore.

Herrera Oria, A. (1949). Pecado, castigo y resurrección de España. Discurso en el acto de homenaje a su Eminencia el cardenal Tedeschini en el Ateneo de Madrid. Madrid: OIE.

Kertzer, D. I. (2014). Il patto col Diavolo. Mussolini e Papa Pio XI. Le relazioni segrete fra il Vaticano e l'Italia fascista. Milano: Saggi Rizzoli.

Leonardis, M. (2014). Fede e diplomazia. Le relazioni internazionali della Santa Sede nell'età contemporanea. Milano: Educatt.

Louzao Villar, J. (2013). Nación y catolicismo en la España contemporánea. Revisitando una interrelación histórica. Ayer, 90, 65-89.

Martínez Álvarez, J. (2015). Un paréntesis «apacible»: las relaciones bilaterales entre España y el Vaticano durante la dictadura de Primo de Rivera. Aportes, 88, 79-114.

Martínez Sánchez, S. (2004). Los papeles perdidos del cardenal Segura (1880-1957). Pamplona: EUNSA.

Menozzi, D. y Moro, R. (2004). Cattolicesimo e totalitarismo. Chiese e culture religiose tra le due guerre mondiali (Italia, Spagna, Francia). Brescia: Morcelliana.

Montero, F. (2008). La Acción Católica en la II República. Alcalá de Henares: Universidad de Alcalá.

- (coord.) (2014). El peso del integrismo en la Iglesia y el catolicismo español del siglo xx. Melanges de la Casa de Velázquez, 44, 131-156.

Nogueira Lousado, A. (1934). Bajo el látigo de Tedeschini. Barcelona: Industrias Gráficas Aribau.

Pagano, S. y Venditti, G. (ed.) (2013). I diari di Achille Ratti, visitatore apostolico in Polonia (1918-1919). Vaticano: Archivio Segreto Vaticano.

Pollard, J. F. (1999). The Unknown Pope. Benedict XV (1914-1922) and the Pursuit of Peace. London: Geoffrey Chapman.

- (2005). Money and the Rise of the Modern Papacy. Cambridge: Cambridge University Press.

- (2014). The Papacy in the Age of Totalitarianism 1914-1958. Oxford: Oxford University Press. Disponible en: https://doi.org/10.1093/acprof:oso/9780199208562.001.0001.

Raguer, H. (2011). La política anticatalanista de la dictadura de Primo de Rivera segons una correspondencia íntima. Analecta Sacra Tarraconensia, 84, 735-838.

Robles Muñoz, C. (2013). La Santa Sede y la II República (1931). De la conciliación al conficto. Madrid: Visión Libros. 
- (2015). Paz o victoria. La Santa Sede y la II República (1934-1939). Madrid: Asociación Cultural y Científica Iberoamericana.

Rodríguez Lago, J. R. (2010). La Iglesia católica y la cuestión nacional en la Galicia de la Segunda República. En M. Esteban de Vega y M. D. de la Calle Velasco (eds.). Procesos de nacionalización en la España contemporánea (pp. 189-209). Salamanca: Universidad de Salamanca.

- (2012a). ¡Salvemos los niños rusos! La Iglesia española y la campaña pontificia en la URSS (1922-1924). Spagna Contemporanea, 42, 27-48.

- (2012b). La batalla eclesial por Madrid (1923-1936). Los conflictos entre Eijo Garay y Federico Tedeschini. Hispania Sacra, 64, Extra, 205- 222.

— (2013). La Iglesia católica y la II República española. Resistencias, progresos y retos pendientes. Hispania nova, 11. Disponible en: http://hispanianova.rediris.es/11/dossier/11d006.pdf.

- (2016). Las redes católicas entre España y los Estados Unidos de América (1919-1939). En J. C. Mercado (ed.). Historical Links between Spain and North America (pp. 75-83). Alcalá de Henares: Instituto Franklin de Estudios Norteamericanos.

- (2017). Deconstruyendo mitos. El factor religioso en la Guerra Civil. En A. Viñas y J. A. Blanco (dirs.). La Guerra Civil española, una visión bibliográfica (pp. 200-218). Madrid: Marcial Pons Digital.

Trullén Floría, R. (2012). Religión y política en la España de los años treinta: el nuncio Federico Tedeschini y la Segunda República. Zaragoza: Institución Fernando el Católico.

Zanatta, L. (1996). Del Estado liberal a la nación católica. Iglesia y ejército en los orígenes del peronismo (1930-1944). Buenos Aires: Editorial de la Universidad de Quilmes.

Zúñiga Sánchez-Cerrudo, T. (1929). Biografía del Dr. Don Federico Tedeschini, Arzobispo de Lepanto, Nuncio Apostólico en España. Madrid: Imp. de G. Hernández y Galo Sáez. 